\title{
C-Reactive Protein and Albumin Ratio Predicts Mortality in Elderly Patients Aged Eighty Years and Over with Non-ST- Segment Elevation Myocardial Infarction
}

\section{C-Reaktif Protein/Albümin Oranı ST-Segment Yükselmesiz Miyokart Enfarktüsü Olan Seksen Yaş ve Üzerindeki Yaşlı Hastalarda Mortaliteyi Öngörür}

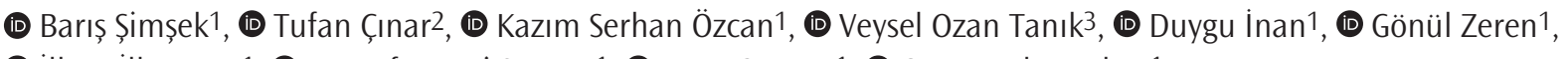

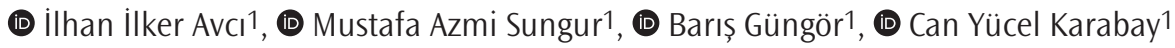

1 University of Health Sciences Turkey, İstanbul Dr. Siyami Ersek Thoracic and Cardiovascular Surgery Training and Research Hospital, Clinic of Cardiology, îstanbul, Turkey

2University of Health Sciences Turkey, İstanbul Sultan Abdülhamid Han Training and Research Hospital, Clinic of Cardiology, İstanbul, Turkey

3University of Health Sciences Turkey, Dıșkapı Yıldırım Beyazıt Training and Research Hospital, Clinic of Cardiology, Ankara, Turkey

\begin{abstract}
Introduction: To explore the prognostic importance for admission of C-reactive protein (CRP)/albumin ratio (CAR) in elderly patients aged 80 years over who presented with non-ST elevation myocardial infarction (non-STEMI).
\end{abstract}

Methods: This retrospective, observational research was related to the clinical data of 528 elderly non-STEMI patients. The study population was categorized based on CAR tertiles as T1, T2, and T3 groups. The CAR was obtained by dividing CRP to albumin level. The main outcome of the research was the in-hospital mortality.

Results: The in-hospital mortality rate during index hospitalization was $5 \%$ ( $n=27$ patients). Cases included in the T3 tertile had significantly higher incidence of cardiopulmonary arrest, cardiac mortality, and all-cause mortality during the index hospitalization [( $15 \%$ vs $4 \%$ vs $0.5 \%)$, ( $10 \%$ vs $1 \%$ vs $0 \%$ ), and ( $13 \%$ vs $2 \%$ vs $0 \%$ ), respectively, $\mathrm{p}<0.05$ each]. In multivariate analysis, chronic renal failure, Killip class of $>1$ on admission, revascularization, and CAR (odds ratio: 1.47, 95\% confidence intervals: $1.23-1.75, p<0.01)$ were independent parameters related with in-hospital mortality. A receiver operating characteristics curve analysis revealed that CAR $>1.12$ predicted in-hospital mortality with a sensitivity of $85 \%$ and specificity of $77 \%$ (area under the curve: $0.813, p<0.01$ ).

Conclusion: In this clinical research, we observed that CAR may be a significant predictor of mortality in elderly patients who were aged 80 years and over with non-STEMI.

Keywords: C-reactive protein/albumin ratio, myocardial infarction, inflammation, acute coronary syndrome

\section{öZ}

Amaç: ST-segment yükselmesi olmayan miyokard enfarktüs (non-STYOME) ile bașvuran 80 yaș üstü yașlı hastalarda bașvuru C-reaktif protein (CRP)/albümin oranının (CAO) prognostik önemini araștırmaktır.

Yöntemler: Bu geriye dönük, gözlemsel çalıșma, STYOME'li 528 yaşlı hastanın klinik verileriyle ilgiliydi. Çalışma popülasyonu, CAO tertillerine göre T1, T2 ve T3 grupları olarak kategorize edildi. CAO'yu, CRP'nin albümin düzeyine bölünmesiyle elde edildi. Çalışmanın birincil ana sonlanımı, hastane içi mortaliteydi.

Bulgular: İndeks hastaneye yatıșta, mortalite $\% 5$ ( $n=27$ hasta) idi. T3 grubuna dahil edilen hastalarda, kardiyopulmoner arrest, kardiyak mortalite ve tüm nedenlere bağlı mortalite hastanede yatış sırasında önemli ölçüde daha yüksek saptandı [( $\% 15$ vs $\% 4$ vs $\% 0,5),(\% 10$ vs $\% 1$ vs $\% 0)$ ve ( $\% 13$ vs $\% 2$ vs $\% 0)$, sırasıyla, her biri için $p<0,05]$. Çok değişkenli analizde; kronik böbrek yetmezliği, bașvuru Killip sınıf $>1$, revaskülarizasyon ve CAO (olasılık oranı: 1,47, 95\% güven aralığı: 1,23-1,75, $p<0,01$ ) hastane içi mortalitenin bağımsız prediktörleri ile ilișkiliydi. Alıcı ișletim karakteristiği eğrisi analizi, CAO >1,12'nin \%85 duyarlılı ve \%77 özgüllük ile hastane içi mortaliteyi öngördügünü ortaya koydu (eğri altındaki alan: 0,813, p<0,01).

Sonuç: Bu klinik araștırmada, STYOME'li 80 yaș ve üstü yașlı hastalarda CAO'nun, mortalitenin önemli bir prediktörü olabileceğini gözlemledik.

Anahtar Kelimeler: C-reaktif protein/albümin oranı, miyokart enfarktüsü, enflamasyon, akut koroner sendrom

Cite this article as/Atıf: Șimșek B, Çınar T, Özcan KS, Tanık VO, İnan D, Zeren G, Avcı ii, Sungur MA, Güngör B, Karabay CY. C-Reactive Protein and Albumin Ratio Predicts Mortality in Elderly Patients Aged Eighty Years and Over with Non-St-Segment Elevation Myocardial Infarction. İstanbul Med J 2021; 22(2): 88-93.

(C) Copyright 2021 by the University of Health Sciences Turkey, Istanbul Training and Research Hospital/Istanbul Medical Journal published by Galenos Publishing House

(C) Telif Hakkı 2021 Sağıı Bilimleri Üniversitesi Istanbul Ĕgitim ve Araştırma Hastanesi/Istanbul Tıp Dergisi, Galenos Yayınevi tarafından basılmıștır. 


\section{Introduction}

Acute coronary syndrome (ACS) is the main cause of deaths worldwide (1). As a consequence of increased life expectancy, the proportion of elderly patients in acute myocardial infarction (AMI) population is rising (2). Patients older than 80 years constitute $20 \%$ of AMI cases, and their mortality and morbidity are significantly elevated compared to younger patients with AMI (3). Thus, early risk stratification by clinical and laboratory parameters as well as patient specific treatment plans in this patient group is crucial to reduce mortality.

Inflammation, which is closely linked to atherosclerosis development, has a vital role in the onset, progression, and destabilization of atherosclerotic plaque that leads to myocardial ischemia due to plaque rupture and thrombosis (4-6). Inflammation can either increase or decrease acute phase proteins in the body. In particular, C-reactive protein (CRP), which is assumed to be a positive acute phase protein, is closely linked to atherosclerosis and cardiovascular disease in previous studies $(7,8)$. In addition, serum albumin, which is accepted to be a negative acute phase protein and indicator of nutritional status, is related with the progression of atherosclerosis and poor cardiovascular events (9).

The CRP/albumin ratio (CAR) is a recently developed inflammationbased bioindex that showed to better predict outcome in a variety of disorders (malignancy, sepsis, and acute medical illness) than each parameters separately (10-13). Moreover, in a recent research, Çınar et al. (14) showed that an elevated CAR is associated with higher in-hospital and long-term mortality rates in patients with ST elevation myocardial infarction (STEMI) undergoing a primary percutaneous coronary intervention $(\mathrm{PCl})$. However, the prognostic significance of this index has not been explored in predicting in-hospital death in elderly cases who were aged 80 years and over and diagnosed with non-STEMI. Hence, this study aimed to examine the prognostic significance of admission CAR in elderly subjects aged 80 years and over with non-STEMI.

\section{Methods}

\section{Data Collection}

This observational and retrospective research was conducted in elderly cases aged 80 years and over with non-STEMI admitted to a tertiary heart center. Exclusion criteria in the present study includes the following: Patients who had hepatobiliary disorder, acute inflammatory status, hematological disorder, end-stage renal disease, acute anemia, coagulopathy, cancer, venous graft-related infarcts, and those who presented with cardiogenic shock or cardiac arrest. Applying the exclusion criteria, a total of 528 non-STEMI elderly participants were enrolled in the present study. Clinical and laboratory data were retrieved from the hospital's electronic database. Non-STEMI was accepted according to the criteria of the European Society of Cardiology non-STEMI guideline (15). Informed consent form each case included in the study and an approval form the Haydarpaşa Numune Training and Research Hospital Local Ethics Committee was obtained (approval number: 2019/KK/157, date: 13.01.2020).

\section{Laboratory Analysis and Echocardiographic Examination}

In all cases, blood samples were obtained following admission to the emergency service. After sampling, complete blood count parameters were immediately analyzed by an ABX Pentra DX 120 hematology device. Biochemical parameters were analyzed by the Roche Cobas Integra 800 device. The CAR was obtained by dividing CRP to albumin level. In all cases, transthoracic echocardiography was performed before discharge using a commercially available machine. From the apical 4-chamber view, left ventricular ejection fraction (LVEF) of each case was estimated using the Simpson method.

\section{Interventional Procedure}

The attending physician decided for whom coronary angiography (CAG) will be performed according to hospital protocol. All cases were treated with two antiplatelet regimen, which was consisted of aspirin and either clopidogrel or ticagrelor loading dose. In all cases undergoing a PCl, intravenous unfractionated heparin $(35-70 \mathrm{IU} / \mathrm{kg}$ ) was used to achieve a periprocedural anticoagulation. A stent implantation during the $\mathrm{PCI}$ procedure was performed in accordance with the current myocardial revascularization guideline (15). The main aim of $\mathrm{PCl}$ procedure was to acquire a residual stenosis of $<10 \%$ with thrombolysis in myocardial infarction-3 flow in the infarct-related artery by a visual evaluation.

\section{Study Outcome and in-hospital Events}

The main outcome of the research was the in-hospital death. In addition, data were collected regarding in-hospital events, such as ventricular tachycardia, ventricular fibrillation, and cardiac mortality, during index hospitalization.

\section{Statistical Analysis}

The International Business Machines SPSS software 21.0 was used to perform all statistical analyses. The number of cases and percentages were utilized for categorical parameters, whereas data was presented as mean \pm standard deviation or median (25-75 intelligence quotients) for continuous variables. The Kolmogorov-Smirnov test was utilized to determine whether normal distribution assumption for continuous variables was provided or not. All categorical variables were analyzed with either a chi-square test or a Fisher's exact test. To evaluate the quantitative data, the Kruskal-Wallis test was used. Univariable and multivariable logistic regression analysis were applied to find out the independent parameters linked with in-hospital death. After performing univariable examination, parameters with $p<0.05$ were selected into a multivariable logistic regression examination. The odds ratio (OR) with 95\% confidence intervals $(\mathrm{Cl})$ were used to present the findings of univariate and multivariate regression analyses. Cut-off value of CAR for in-hospital mortality with a highest sensitivity and specificity was calculated by nonparametric receiver operating characteristic (ROC) curve analysis. The model fit of multivariable analysis was assessed with Hosmer-Lemeshow test, which did not suggest a lack of fit $\left(X^{2}=8.19\right.$, $p=0.41)$. A $p$-value of $<0.05$ was accepted to be a statistically significant.

\section{Results}

The mean age of the study cohort was $85 \pm 4$ years. In total, 314 (59\%) cases were female. The in-hospital mortality rate during index hospitalization was $5 \%$ ( $n=27$ patients). We categorized the study cohort based on CAR tertiles. Participants with CAR value of $<0.24(n=176)$ were stratified into T1 tertile, participants with CAR value of $0.24-0.73(n=176)$ 
were stratified into T2 tertile, and participants with CAR value of $>0.73$ $(n=176)$ were stratified into T3 tertile.

The baseline demographic characteristics and laboratory findings of all cases are displayed in Table 1. T3 participants had a higher prevalence of diabetes, chronic renal failure (CRF) and active smoking compared to those in the other tertiles ( $p<0.05$ for each). T3 tertile participants had an elevated Killip class and heart rate but a significantly decreased systolic and diastolic blood pressure upon admission compared to those stratified into T1 and T2 tertiles ( $p<0.05$ for each). In terms of echocardiographic and laboratory findings, T3 tertile participants had a lower LVEF, albumin, and hemoglobin levels but higher CRP, white blood cell (WBC) counts, CAR, troponin, and creatinine kinase-myocardial band levels ( $p<0.05$, for each). Both groups were indifferent in terms of premedication.
Both invasive CAG and PCI were significantly less performed in T3 tertile participants ( $p<0.05$ for each). T3 tertile participants had significantly elevated incidence of cardiopulmonary arrest, cardiac mortality, and all-cause mortality during the index hospitalization $[n=27(15 \%)$ vs $n=7$ (4\%) vs $n=1(0.5 \%), n=18(10 \%)$ vs $n=2(1 \%)$ vs $n=0(0 \%)$ and $n=23(13 \%)$ vs $n=4(2 \%)$ vs $n=0(0 \%)$, respectively, $p<0.05$ for each) (Table 2$)$.

Effects of different variables in in-hospital death were explored using univariable and multivariable logistic regression analysis, as shown in Table 3. Congestive heart failure, CRF, Killip class $>1$, WBC count, CRP, albumin, revascularization during index hospitalization, and CAR were predictors of in-hospital death based on a univariable analysis. According to a multivariable model that adjusted for the aforementioned parameters, CRF (OR: 3.53, 95\% Cl: 1.09-13.44, $p=0.04$ ), Killip class $>1$ (OR: 4.06, 95\% Cl: 1.72-9.55, $\mathrm{p}=0.013$ ), revascularization during index hospitalization (OR: $0.25,95 \% \mathrm{Cl}: 0.07-0.94, \mathrm{p}=0.04)$ and CAR (OR: 1.47 ,

Table 1. Baseline properties and laboratory results of all patients according to CAR tertiles

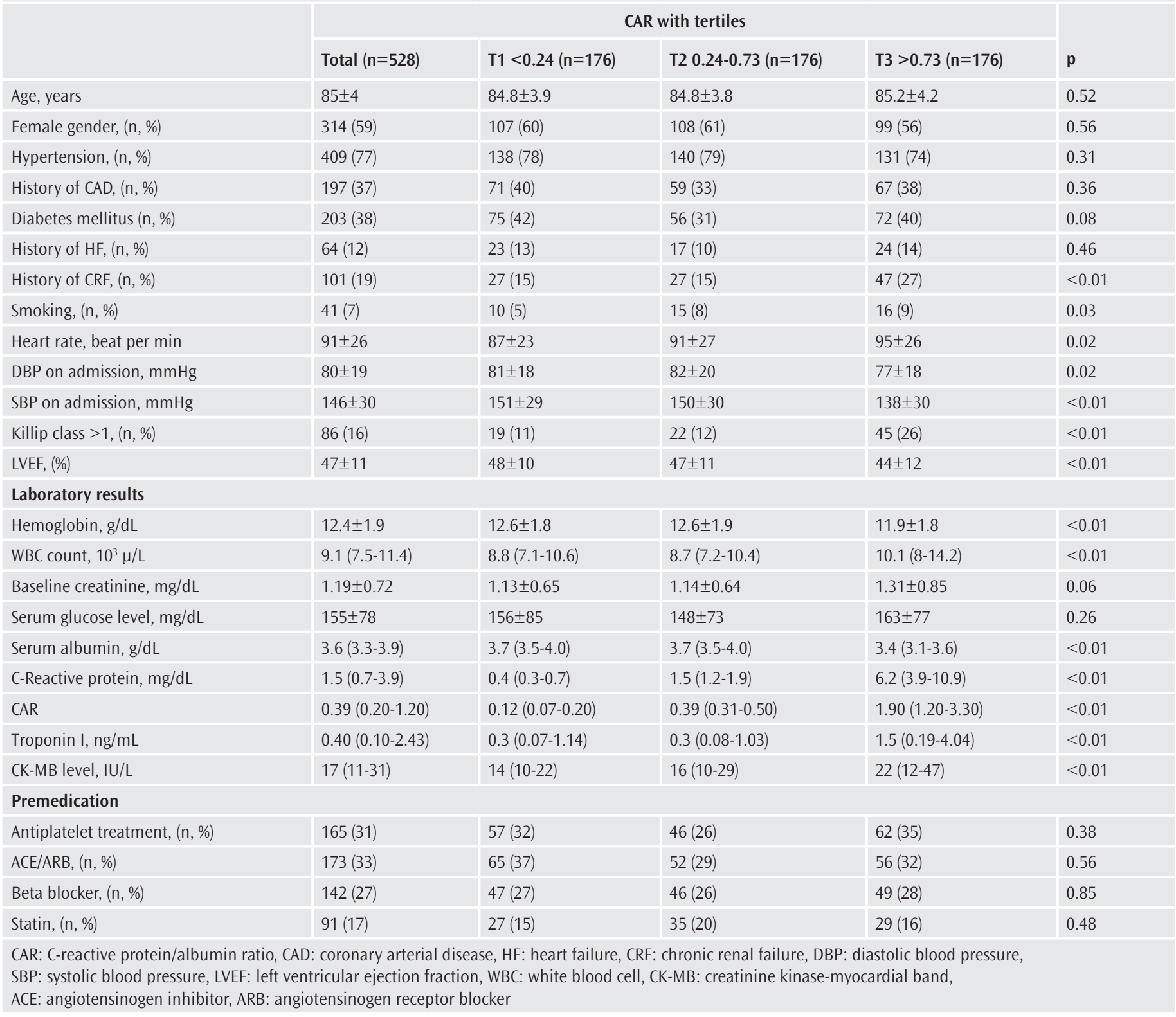


95\% Cl: 1.23-1.75, $\mathrm{p}=0.003)$ were independent predictors linked with in-hospital death.

An ROC analysis revealed that CAR $>1.12$ predicted in-hospital mortality with a sensitivity of $85 \%$ and specificity of $77 \%$ [area under the curve (AUC): $0.813, p<0.01]$. AUC of CAR was significantly larger compared to AUC of CRP (AUC: 0.785) and albumin levels (AUC: 0.665), which indicates the discriminative power of CAR over CRP and albumin levels for prediction of in-hospital mortality $(p=0.02$ and $p<0.01$, respectively) (Figure 1).

\section{Discussion}

In this research, CAR was noted as a significant predictor of in-hospital death in elderly cases aged 80 years and over with non-STEMI. In addition, the combination of CRP and serum albumin into single bioindex, namely CAR, might predict poor outcomes better than either parameter alone.

Improved living condition and access to healthcare system lead to an increase in life expectancy, especially in elderly patients. As a result, an increase was noted in the proportion of participants presenting with ACS, including non-STEMI $(16,17)$. However, age is an important predictor of poor clinical outcomes in AMI, and the potential benefit of reperfusion strategies in this patient group is controversial (18). Therefore, it is important to identify a prognostic biomarker to differentiate patients for whom an invasive strategy would be beneficial to better manage limited medical resources.

AMI causes a more severe inflammatory reaction particularly in patients with large infarction (19). This inflammatory reaction during AMI can

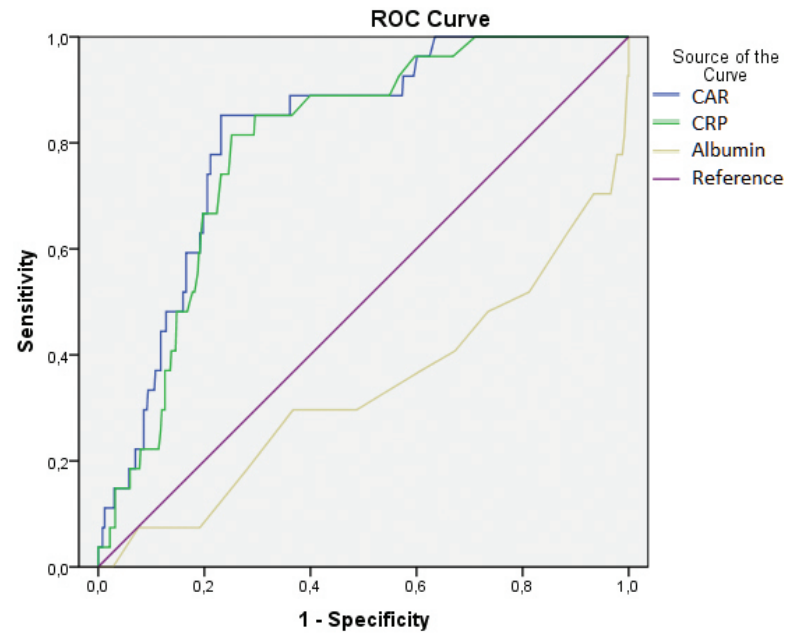

Figure 1. Receiver operating characteristics curve analysis of CAR, CRP, and albumin

CAR: C-reactive protein/albumin ratio, CRP: C-reactive protein, ROC: Receiver operating characteristics

Table 2. Coronary angiographic findings and in-hospital events of all patients according to CAR tertiles

\begin{tabular}{|c|c|c|c|c|c|}
\hline & \multicolumn{5}{|c|}{ CAR with tertiles } \\
\hline & Total $(n=528)$ & $\mathrm{T} 1<0.24(\mathrm{n}=176)$ & T2 $0.24-0.73(n=176)$ & T3 >0.73 $(n=176)$ & $\mathbf{p}$ \\
\hline \multicolumn{6}{|l|}{ Revascularization } \\
\hline $\mathrm{PCl},(\mathrm{n}, \%)$ & $142(27)$ & $57(32)$ & $51(29)$ & $34(19)$ & 0.02 \\
\hline CABG, $(n, \%)$ & $44(8)$ & $16(9)$ & $9(5)$ & $19(11)$ & 0.14 \\
\hline $\mathrm{CPA},(\mathrm{n}, \%)$ & $35(6)$ & $1(0.5)$ & $7(4)$ & $27(15)$ & $<0.01$ \\
\hline Cardiac mortality, (n, \%) & $20(3)$ & $0(0)$ & $2(1)$ & $18(10)$ & $<0.01$ \\
\hline All-cause mortality, (n, \%) & $27(5)$ & $0(0)$ & $4(2)$ & $23(13)$ & $<0.01$ \\
\hline
\end{tabular}

Table 3. Univariable and multivariable logistic regression analysis for prediction of in-hospital mortality

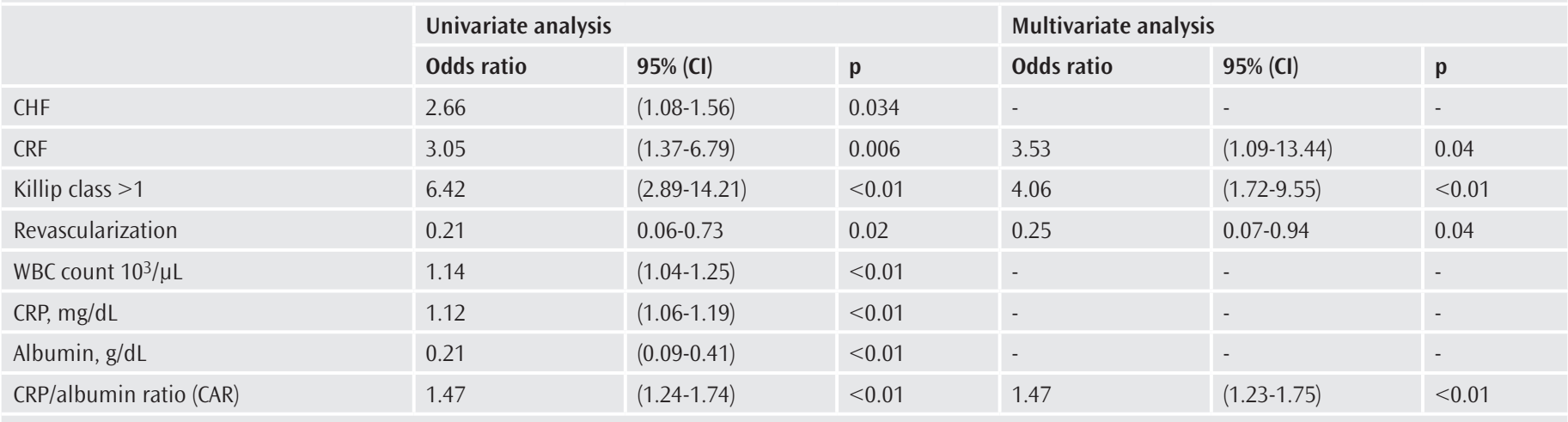

CI: Confidence interval, CHF: congestive heart failure, CRP: C-reactive protein, WBC: white blood cell, CRF: chronic renal failure, CAR: C-reactive protein/albumin ratio 
lead to elevation of CRP levels. In previous studies, high CRP levels have been found to be a poor predictor of cardiovascular events $(20,21)$. The inflammatory process can cause a decrease in albumin in the body besides elevation CRP levels. Decreased albumin levels are closely related with an elevated morbidity and mortality risk in various forms of cardiovascular disease (22). Previous studies reported that higher CRP levels with lower albumin levels are linked with increases mortality rates in patients with chronic kidney disease $(23,24)$. Moreover, Wada et al. (25) observed that both low serum albumin and high CRP levels had a synergistic adverse effect on the long-term risk of major adverse events in cases undergoing PCI. Thus, both CRP and serum albumin status can be used to identify patients with an exaggerated inflammatory condition.

The CAR is a newly defined systemic inflammatory bioindex that combines both CRP and albumin (4). Several researches have explored the prognostic value of CAR in participants with cardiovascular disease $(14,26-28)$. In a recent research by Çınar et al. (14) an elevated CAR was observed to be independently linked with elevated in-hospital and longterm mortality in STEMI cases treated with a primary $\mathrm{PCI}$. Moreover, Cağdaş et al. (27) observed that elevated CAR is related with a more severe form of coronary artery disease according to the Syntax score. In addition, Duman et al. (28) observed that CAR could be used as a useful and reliable marker in predicting coronary thrombus burden in cases with ACS. However, to our knowledge, the prognostic importance of the CAR has not been investigated in elderly non-STEMI cases. In our study, patients were classified from low to high (T1, T2, and T3) according to CAR values during index hospitalization. Both cardiac and all-cause mortality rates was found to be significantly higher in cases included the T3 tertile compared to those in the T2 and T1 tertiles. In addition, CAR was independently linked with in-hospital mortality according to our multivariable examination.

Our study results are considered to be clinically important regarding the follow-up and treatment plans for elderly patients with non-STEMI. Particularly, CAR may be a part of risk stratification in this high-risk patient group. In addition, it may be used to identify patients who need closely clinical follow-up and a more aggressive treatment approach if validated in large scale prospective trials.

\section{Study Limitations}

Our study had the following limitations. First, results of the study were based on retrospective design, which might be related with a selection bias. However, all consecutive elderly non-STEMI cases were included in this analysis. Second, our study was conducted in one geographical area, thus, restricting the generalizability of our results to other geographical areas. Third, we considered a possible presence of residual confounding from unmeasured variables, which might affect the final outcome of the study. Finally, further multi-center researches enrolling more patients are necessary to elucidate the exact relation between CAR values and in-hospital mortality in elderly patients with non-STEMI.

\section{Conclusion}

We have found that elevated CAR is a predictor of poor prognosis in elderly participants with Non-STEMI. Thus, as a simple and inexpensive inflammatory index, CAR might be used for early treatment plans to decrease in-hospital deaths in such patients.

Ethics Committee Approval: The approval form the Haydarpaşa Numune Training and Research Hospital Local Ethics Committee was obtained (approval number: 2019/KK/157, date: 13.01.2020).

Informed Consent: Informed consent was obtained form each case included in the study.

Peer-review: Externally and internally peer-reviewed.

Authorship Contributions: Concept - B.S,., K.S.Ö., B.G., C.Y.K.; Design B.Ş., T.C.., K.S.Ö., V.O.T., D.I., B.G.; Data Collection or Processing - B.S., V.O.T., D.I., G.Z., I.I.A., M.A.S.; Analysis or Interpretation - B.S,., T.Ç., K.S.Ö., B.G., C.Y.K.; Literature Search - B.S., T.Ç., K.S.Ö., M.A.S., C.Y.K.; Writing B.Ş., T.Ç., K.S.Ö.

Conflict of Interest: No conflict of interest was declared by the authors.

Financial Disclosure: The authors declared that this study received no financial support.

\section{References}

1. Yeh RW, Sidney S, Chandra M, Sorel M, Selby JV, Go AS. Population trends in the incidence and outcomes of acute myocardial infarction. N Engl J Med 2010; 362: 2155-65.

2. Goldberg RJ, McCormick D, Gurwitz JH, Yarzebski J, Lessard D, Gore JM Age-related trends in short- and long-term survival after acute myocardial infarction: a 20-year population-based perspective (1975-1995). Am J Cardiol 1998; 82: 1311-7

3. Singh M, Mathew V, Garratt KN, Berger PB, Grill DE, Bell MR, et al. Effect of age on the outcome of angioplasty for acute myocardial infarction among patients treated at the Mayo Clinic. Am J Med 2000; 108: 187-92.

4. Wada H, Dohi T, Miyauchi K, Shitara J, Endo H, Doi S, et al. Preprocedural HighSensitivity C-Reactive Protein Predicts Long-Term Outcome of Percutaneous Coronary Intervention. Circ J 2016; 81: 90-5.

5. Ahmed MS, Jadhav AB, Hassan A, Meng QH. Acute phase reactants as nove predictors of cardiovascular disease. ISRN Inflamm 2012; 2012: 953461.

6. Raggi P, Genest J, Giles JT, Rayner KJ, Dwivedi G, Beanlands RS, et al. Role of inflammation in the pathogenesis of atherosclerosis and therapeutic interventions. Atherosclerosis 2018; 276: 98-108.

7. Gulhar R, Ashraf MA, Jialal I. Physiology, acute phase reactants. 2020 May 4. In: StatPearls [Internet]. Treasure Island (FL): StatPearls Publishing; 2020

8. Koenig W, Rosenson RS. Acute-phase reactants and coronary heart disease Semin Vasc Med 2002; 2: 417-28.

9. Schillinger M, Exner M, Mlekusch W, Amighi J, Sabeti S, Schlager O, et al Serum albumin predicts cardiac adverse events in patients with advanced atherosclerosis - interrelation with traditional cardiovascular risk factors. Thromb Haemost 2004; 91: 610-8.

10. Fairclough E, Cairns E, Hamilton J, Kelly C. Evaluation of a modified early warning system for acute medical admissions and comparison with C-reactive protein/albumin ratio as a predictor of patient outcome. Clin Med 2009; 9: 30-3.

11. Kinoshita A, Onoda H, Imai N, Iwaku A, Oishi M, Tanaka K, et al. The C-reactive protein/albumin ratio, a novel inflammation-based prognostic score, predicts outcomes in patients with hepatocellular carcinoma. Ann Surg Oncol 2015; 22: $803-10$.

12. Ranzani OT, Zampieri FG, Forte DN, Azevedo LC, Park M. C-reactive protein/ albumin ratio predicts 90-day mortality of septic patients. PLoS One. 2013; 8: e59321. 
13. Ge X, Cao Y, Wang H, Ding C, Tian H, Zhang X, et al. Diagnostic accuracy of the postoperative ratio of $\mathrm{C}$-reactive protein to albumin for complications after colorectal surgery. World J Surg Oncol 2017; 15: 15.

14. Çınar T, Cağdas M, Rencüzoğulları I, Karakoyun S, Karabağ Y, Yesin M, et al. Prognostic efficacy of C-reactive protein/albumin ratio in ST elevation myocardial infarction. Scand Cardiovasc J 2019; 53: 83-90.

15. Roffi M, Patrono C, Collet JP, Mueller C, Valgimigli M, Andreotti F, et al; ESC Scientific Document Group. 2015 ESC Guidelines for the management of acute coronary syndromes in patients presenting without persistent ST-segment elevation: Task Force for the Management of Acute Coronary Syndromes in Patients Presenting without Persistent ST-Segment Elevation of the European Society of Cardiology (ESC). Eur Heart J 2016; 37: 267-315.

16. Ruff CT, Braunwald E. The evolving epidemiology of acute coronary syndromes. Nat Rev Cardiol 2011; 8: 140-7.

17. Koller L, Rothgerber DJ, Sulzgruber P, El-Hamid F, Förster S, Wojta J, et al. History of previous bleeding and C-reactive protein improve assessment of bleeding risk in elderly patients ( $\geq 80$ years) with myocardial infarction. Thromb Haemost 2015; 114: 1085-91.

18. Tespili M, Guagliumi G, Valsecchi O, Musumeci G, Vassileva A, Saino A, et al. Inhospital clinical outcome in elderly patients with acute myocardial infarction treated with primary angioplasty. Ital Heart J 2003; 4: 193-8.

19. Prabhu SD, Frangogiannis NG. The biological basis for cardiac repair after myocardial infarction: from inflammation to fibrosis. Circ Res 2016; 119: 91 112 .

20. Danesh J, Wheeler JG, Hirschfield GM, Eda S, Eiriksdottir G, Rumley A, et al. C-reactive protein and other circulating markers of inflammation in the prediction of coronary heart disease. N Engl J Med 2004; 350: 1387-97.

21. Ridker PM. High-sensitivity C-reactive protein: potential adjunct for global risk assessment in the primary prevention of cardiovascular disease. Circulation 2001; 103: 1813-8.
22. Murat SN, Kurtul A, Yarlioglues M. Impact of serum albumin levels on contrastinduced acute kidney injury in patients with acute coronary syndromes treated with percutaneous coronary intervention. Angiology 2015; 66: 732-7.

23. Menon V, Greene T, Wang X, Pereira AA, Marcovina SM, Beck GJ, et al. C-reactive protein and albumin as predictors of all-cause and cardiovascular mortality in chronic kidney disease. Kidney Int 2005; 68: 766-772.

24. Takahashi R, Ito Y, Takahashi H, Ishii H, Kasuga H, Mizuno M, et al. Combined values of serum albumin, C-reactive protein and body mass index at dialysis initiation accurately predicts long-term mortality. Am J Nephrol 2012; 36: $136-43$.

25. Wada H, Dohi T, Miyauchi K, Doi S, Naito R, Konishi H, et al. Independent and Combined Effects of Serum Albumin and C-Reactive Protein on Long-Term Outcomes of Patients Undergoing Percutaneous Coronary Intervention. Circ J 2017; 81:1293-1300.

26. Çalık AN, İnan D, Karataş MB, Akdeniz E, Genç D, Çanga Y, et al. The association of preprocedural C-reactive protein/albumin ratio with in-stent restenosis in patients undergoing iliac artery stenting. J Cardiovasc Thorac Res 2020; 12 : 179-84.

27. Cağdaş M, Rencüzoğulları I, Karakoyun S, Karabağ Y, Yesin M, Artaç I, et al. Assessment of relationship between C-reactive protein to albumin ratio and coronary artery disease severity in patients with acute coronary syndrome. Angiology 2019; 70: 361-8.

28. Duman H, Çinier G, Bakırcı EM, Duman H, Şimșek Z, Hamur H, et al. Relationship Between C-Reactive Protein to Albumin Ratio and Thrombus Burden in Patients With Acute Coronary Syndrome. Clin Appl Thromb Hemost 2019; 25: 1076029618824418. 